\title{
A new multi-zone model for porosity distribution in Al-Si alloy castings
}

Tiedje, Niels Skat; Taylor, John A.; Easton, Mark A.

\section{Published in:}

Acta Materialia

Link to article, DOI:

10.1016/j.actamat.2013.01.064

Publication date:

2013

Link back to DTU Orbit

Citation (APA):

Tiedje, N. S., Taylor, J. A., \& Easton, M. A. (2013). A new multi-zone model for porosity distribution in Al-Si alloy castings. Acta Materialia, 61(8), 3037-3049. https://doi.org/10.1016/j.actamat.2013.01.064

\section{General rights}

Copyright and moral rights for the publications made accessible in the public portal are retained by the authors and/or other copyright owners and it is a condition of accessing publications that users recognise and abide by the legal requirements associated with these rights.

- Users may download and print one copy of any publication from the public portal for the purpose of private study or research.

- You may not further distribute the material or use it for any profit-making activity or commercial gain

- You may freely distribute the URL identifying the publication in the public portal

If you believe that this document breaches copyright please contact us providing details, and we will remove access to the work immediately and investigate your claim. 


\title{
A new multi-zone model for porosity distribution in Al-Si alloy castings
}

\author{
Niels Skat Tiedje ${ }^{1}$, John A. Taylor ${ }^{2}$, Mark A. Easton ${ }^{3}$ \\ ${ }^{1}$ Dept. of Mechanical Engineering, Technical University of Denmark (DTU), DK-2800 Kgs. \\ Lyngby, Denmark \\ ${ }^{2}$ CAST Co-operative Research Centre, School of Mechanical \& Mining Engineering, The \\ University of Queensland, Brisbane, Australia \\ ${ }^{3}$ CAST Co-operative Research Centre, Department of Materials Engineering, Monash University, \\ Melbourne, Australia
}

\section{Corresponding author}

Niels Skat Tiedje, Dept. of Mechanical Engineering, Technical University of Denmark (DTU), building 427, room 306b, DK-2800 Kgs. Lyngby, Denmark. E-mail: nsti@mek.dtu.dk, ph.+45 45254719 , fax. +4545934570 .

\begin{abstract}
A new multi-zone model is proposed that explains how porosity forms in various regions of a casting under different conditions and leads to distinct zonal differences in pore shape, size and distribution. This model was developed by considering the effect of cooling rate on solidification and distribution of porosity in Al-Si alloys cast as plates in moulds made with silica, ilmenite or zirconia sand cores or steel chills facing the major plate faces. The alloys cast were Al-7wt $\% \mathrm{Si}$ and $\mathrm{Al}-12.5 \mathrm{wt} \% \mathrm{Si}$ in unmodified and modified forms, the latter with either $\mathrm{Na}$ or $\mathrm{Sr}$ addition. It is found that regardless of cooling condition, Si content and modification treatment the microstructure can be divided into three zones of varying size (across the casting thickness) that are determined by the local cooling conditions and the nucleation and growth mode of the Al-Si eutectic. The zones are: (1) an outer shell-like zone where directional columnar dendritic grains and a fine celled, coherent eutectic form a low porosity shell at the casting surface; (2) a transitional zone where equiaxed, eutectic cells grow between columnar dendritic grains and irregular pores become trapped in the mush; and finally, (3) a central zone where the thermal gradient is low and equiaxed dendritic grains and eutectic cells grow at the centre of the casting and larger rounded pores tend to form. The paper discusses how Si content, modification type and cooling conditions influence the location and size (i.e. depth) of each of these zones and how the distribution of porosity is thus affected.
\end{abstract}

Keywords: Al-Si alloys, Eutectic solidification, Heat flow and solidification, Microstructure, Porosity 


\section{Introduction}

The location, type and size of pores formed in castings are critical for subsequent applications in various ways. Sub-surface pores are exposed by machining and affect aesthetic appearance, the presence of large pores at stressed areas detrimentally affect fatigue life [1], and interconnected porosity has an adverse effect on pressure tightness. Numerical modelling of solidification has been reasonably effective in predicting the likely location of significant porosity/shrinkage in castings, but the finer details are still lacking. A more precise mechanistic description to assist with modelling is required.

The formation of casting porosity is known to be significantly influenced by the growth morphology of the solidifying alloy, and in particular the feeding of liquid through the semi-solid mush [2]. It is therefore important to understand the operative growth morphologies in order to understand pore formation. It is generally accepted that castings contain three macrostructural zones based on the primary grain structure: a thin and densely packed chill zone at the surface, followed by a columnar zone with directional grains, and an equiaxed zone in the centre [3]. These three regions are not all necessarily observed in any one casting, their actual occurrence being dependent upon alloy composition, solidification conditions and the addition of grain refiner. Of particular importance though is the Columnar to Equiaxed Transition (CET), which has been considered by many authors [3-7] and is attributed to changes in the spatial temperature gradient, local cooling rate and nucleation density in the melt. A similar transition is found in eutectics [8].

In Al-Si foundry alloys, there are two major reactions that occur, one being the formation of the primary $\alpha$-Al phase, the second being the binary Al-Si eutectic. A series of more complex minor reactions may also occur with increasing complexity of the alloy chemistry. Even in a binary alloy this complicates feeding as the growth modes of both the $\alpha$-Al phase and the eutectic need to be taken into account. Complicating matters further is the common practice of adding $\mathrm{Na}$ or $\mathrm{Sr}$ modifiers during the production of hypoeutectic and eutectic Al-Si alloy castings to alter the morphology of the eutectic silicon so that it becomes fibrous rather than acicular, thus improving the alloy's mechanical properties, particularly its ductility [2].

The position and amount of porosity is known to be affected by various factors including the cooling conditions, particularly its directionality, the amount and morphology of the primary phase and the type of modification used. Recent research by Felberbaum and Rappaz [9] has shown that the shape of pores in Al-Si alloys is influenced by the fraction primary dendrites and the dendrite arm spacing. They also conclude that the gas content in the melt has major influence on the shape of pores.

In recent years it has been shown that modification not only changes the morphology of the eutectic silicon but also changes the mode of eutectic solidification [10-15]. Both $\mathrm{Sr}$ and $\mathrm{Na}$ lower the temperature at which the eutectic grows. Addition of $\mathrm{Na}$ forces the eutectic to grow at an almost constant, low undercooling which leads to the formation of a fine, uniformly structured eutectic [10]. Strontium creates an initial undercooling followed by recalescence during which the growth temperature of the eutectic increases gradually to reach a maximum slightly below the unmodified eutectic growth temperature. Towards the end of solidification, the undercooling increases again as the final melt pools trapped between the eutectic cells ${ }^{1}$ solidify [11]. The varying growth conditions

1 To avoid confusion, in this paper, the term "cell" (cell size, cell shape/morphology, etc.) will be exclusively used to describe a discrete entity of Al-Si eutectic, i.e. the related $\mathrm{Al}$ and Si components, formed from a unique eutectic nucleation event. The term "grain" (grain size, grain shape/morphology, etc.) will be used exclusively to describe a 
arising from $\mathrm{Sr}$ addition create a well modified eutectic but the scale of the Si particles usually varies in size from fine in the centre to coarser at the edge of the eutectic cells.

It has been shown that both $\mathrm{Na}$ and $\mathrm{Sr}$ react with $\mathrm{P}$ in the liquid such that the population of $\mathrm{AlP}$ particles that serve as nuclei for the $\mathrm{Si}$ in the eutectic cells is reduced $[12,13]$. The reduction of available nuclei suppresses formation of the eutectic, and as a result the eutectic undercooling and eutectic cell size are both increased.

When there is a sufficient thermal gradient, Na-modified eutectic cells grow with a relatively coherent, planar front [10-14]. This is not the case for Sr-modified eutectic cells. They are large, approximately spherical and well distributed, forming a mushy zone while eutectic solidification takes place [14-17].

A recent investigation by Tiedje et al [16]. has shown that the ability of Al-Si alloys to form a solid shell and subsequently be responsive to feeding depends very much on the method of modification. In that work it was also shown that the shape of the pores formed is determined by the growth of both primary dendritic grains and Al-Si eutectic cells. Upon reflection, it has become evident that shape, size and distribution of porosity in Al-Si alloys was characteristically different in three regions/zones of the casting: (1) the solid shell at the casting surface; (2) an intermediate region where large eutectic cells grow between more or less columnar dendritic grains; and (3) the centre of the casting where the eutectic cells form between equiaxed dendritic grains.

The present work is a further investigation into the factors that control the formation of these three zones, and how porosity forms within each of them. In particular, the effect of cooling conditions on solidification and porosity formation in Al-Si alloys in unmodified, Na-modified and Srmodified forms is investigated. This is used to propose a new description of how modification and process conditions influence porosity formation in castings.

\section{Experimental procedure}

In this work, several castings, each consisting of three plates $(120 \times 160 \times 15 \mathrm{~mm})$ with individual feeders, were produced using multi-section silica sand moulds. The mould was designed such that exchangeable cores could be inserted to face each of the large plate faces $(120 \times 160 \mathrm{~mm})$. These face cores were made with either the same silica sand as the rest of the mould parts, or with other materials. To create a range of cooling conditions, exchangeable cores made of zircon sand $\left(\mathrm{ZrSiO}_{4}\right)$, ilmenite sand $\left(\mathrm{FeTiO}_{3}\right)$ or of mild steel (from now on termed "chills") were used. A detailed description of mould design and assembly can be found in reference [16].

The cooling ability, $\beta$, of a particular mould material, i.e. the mould's ability to extract energy from the casting can be defined as [2]:

$$
\beta=\sqrt{k \rho c_{p}}
$$

where $k, \rho$ and $c_{p}$ are thermal conductivity, density and heat capacity of the mould material, respectively.

For the plates cast between the steel chills heat flow is also controlled by the heat transfer coefficient between the casting and chill. The cooling ability as described in Equation 1 is therefore

discrete entity of primary $\alpha$-Al phase, i.e. dendritic or globular-like, equiaxed or columnar in form, formed from a unique nucleation event. 
not fully sufficient to describe the mould material's influence on cooling conditions but it gives a good approximation of how cooling conditions change when mould materials are changed [2].

The cooling ability of the four mould materials used in this investigation was calculated using data from several sources [18-20] and the obtained values are listed in Table 1. Cooling ability increases by 30 and $80 \%$ by changing from silica sand to ilmenite or zircon sand, respectively. The cooling ability of the steel chill is 18 times larger than that of silica sand.

Two different alloys were used for the experiments: hypoeutectic A1-7\% Si and near-eutectic Al$12.5 \% \mathrm{Si}$. The first was sourced directly from a commercial alloy with the composition given in Table 2. Apart from Al and Si the only other element of consequence is $0.11 \% \mathrm{Fe}$. The $12.5 \% \mathrm{Si}$ alloy was made by adding commercially pure $\mathrm{Si}(>99 \%)$ to the Al-7\% Si alloy. Note: all compositions in this work are given in weight percentage (wt\%). Alloys were prepared and cast in unmodified form or else modified with $\mathrm{Na}$ or Sr. Full details of casting lay out, melting, degassing and modification procedures are given in a previous paper [16].

Full thickness samples were taken from the centre of each plate, i.e. $80 \mathrm{~mm}$ from the top of the casting and $60 \mathrm{~mm}$ from the side. The cross-sectional samples were mounted in resin, ground and polished using standard practices and then finished with $0.04 \mu \mathrm{m}$ colloidal silica.

Macro photographs were taken using a stereo microscope with a circular light source at low magnification. Micrographs at low to medium magnification were taken using a Reichert Polyvar optical microscope. Secondary dendrite arm spacing (SDAS) measurements were made using a linear intercept method at 3 locations on each sample; 1,3 and $7.5 \mathrm{~mm}$ from the major plate surface, the latter being the casting centreline.

Pore size, shape and amount were measured on micrographs taken of each test alloy cast in silica sand moulds and chill moulds using ImagePro+ image analysis software. The pixel size was $1 \mu \mathrm{m}$. White areas with an average diameter less than $0.1 \mathrm{~mm}$ were considered as either very small pores, coarse Si particles or artefacts from sample preparation and thus omitted from the pore count. This limit was chosen because the total area of porosity changed little and the number of particles counted increased rapidly as the limit was lowered. In each sample, the three zones were identified and pore measurements were carried out on an area covering almost the entirety of each zone. The shape factor "Roundness", defined as: Roundness $=4 \pi$ Area / Perimeter, was calculated based on the measured values of area and perimeter for the pores.

\section{Results}

Before considering the plate casting as a three zone solidification object, it is necessary to describe the two key microstructural components that contribute to the definition of the zones in our proposed model. These are the primary $\alpha$-Al phase and the Al-Si eutectic.

As initial examples, consider the near-surface macrostructures of the two alloys shown in Figure 1: a Na-modified 7\% Si alloy (left) cast in a sand mould (i.e. between silica sand cores) and a Srmodified $12.5 \% \mathrm{Si}$ alloy (right) cast between steel chills. In both images, the primary Al dendrites appear black, with coarse Si particles ("Si") and larger pores ("P") appearing white. In the 7\% Si alloy eutectic cells are outlined by light grey contours. In the $12.5 \% \mathrm{Si}$ alloy eutectic cells are not easily discernible close to the chill, but about $3 \mathrm{~mm}$ into the casting the boundaries also begin to appear as lighter lines. Coarse Si particles and pores are most frequently found along these cell boundaries. 


\subsection{Solidification of the Primary Phase}

During the initial stage of solidification, primary $\alpha-\mathrm{Al}$ dendrites grow directionally from the casting surface towards the centre (note, this is the classic columnar zone, not the first thin chill zone which can be effectively ignored in most cases, e.g. in castings produced in sand moulds). In the sand cast plates this directional zone is narrow and contains relatively coarse dendrites. In the chilled samples the zone is wider and the dendrite arm spacing is small at the surface, but increases as the cooling rate reduces closer to the centre. As seen in Figure 1, dendrites are also present in the near-eutectic alloy samples. The amount varies with the type of modification. The unmodified and Sr-modified near eutectic alloy castings contain few dendrites while the Na-modified alloy has a higher fraction of very fine dendrites near the surface.

\subsubsection{Columnar to Equiaxed Transition (CET)}

At some distance into the castings the directional columnar grain growth ends and instead becomes equiaxed. The approximate positions of the CET are shown in Figure 1 as solid white lines. The thickness of the columnar zone varies with local cooling conditions. As a casting shrinks during solidification, a gap forms between the casting and the mould wall. Since the contraction is not perfectly uniform, the size of the gap varies over the surface of the casting. The resulting variation in local cooling conditions is most likely the reason for the variation in the position of the CET. The CET is more easily observed in modified castings, where the coarse eutectic $\mathrm{Si}$ in the unmodified castings makes it more difficult to see. However, it can be readily identified on closer inspection at higher magnification. Figure 2 shows macrographs from example chill cast samples on which the varying CET positions are marked (solid white lines) for the full range of alloy conditions. The CET for each sample (i.e. alloy type and cooling condition) was measured from the relevant macrographs by drawing a line that followed the location of the transition and then measuring the average distance between it and the surface. The positions of the CET are compared in Figure 3.

\subsubsection{Secondary Dendrite Arm Spacing (SDAS)}

The other key microstructural parameter of the primary phase is the SDAS. It was measured at three locations in all samples except for the unmodified samples of the $12.5 \% \mathrm{Si}$ alloy where the microstructure made it impossible to obtain a meaningful intercept count.

Since there was no measurable difference observed in SDAS between unmodified, Na- and Srmodified castings for a given Si content and cooling condition, the measurements were pooled and averaged. These mean values are plotted as a function of distance from the casting surface in Figure 4 with $95 \%$ confidence intervals shown.

Figure 4a shows SDAS for the 7\% Si alloys for the four mould materials used in the investigation. The efficiency of the steel chill is clearly seen with the SDAS significantly lower than for castings made using any of the sand mould materials. In the chill cast samples the SDAS increases almost linearly towards the centre of the casting. There is little difference between SDAS in castings made with the three different sands. However, SDAS in the casting made with zircon sand cores are approximately $5 \mu \mathrm{m}$ smaller than in castings made with other sand cores. This indicates that the increased cooling ability of the zircon sand does have a moderate effect on the microstructure of the castings. In each case, SDAS is fine near the surface, increases quickly and then levels off towards the centre of the castings.

The SDAS data for the $12.5 \% \mathrm{Si}$ alloy is shown in Figure $4 \mathrm{~b}$. The observations are similar to above although both ilmenite and zircon sand cores seem to reduce the SDAS near the surface of the castings relative to silica sand. At 1 and $3 \mathrm{~mm}$ from the surface, the SDAS in the $12.5 \%$ alloy is 
significantly lower than in the 7\% Si alloy, while at the centre of the castings the SDAS is similar for both alloys.

\subsection{Eutectic Solidification}

\subsubsection{Dense-Packed to Free Growth Transition (DFT)}

$\mathrm{Al}-\mathrm{Si}$ eutectic cells nucleate in the interdendritic regions (from the surface of $\mathrm{Al}$ dendrites in unmodified alloys and independently in modified alloys $[10,11,14,15,17])$ and then grow into the surrounding intergranular areas, the extent depending on the scale of the eutectic cells. In Figure 1 the eutectic cell boundaries are distinguished by the variation in shade which is a result of variations in the size and shape of the eutectic Si particles, as discussed in Tiedje et al. [16] Close to the casting surface the eutectic cells appear to grow in a densely-packed structure (i.e. simultaneously and in close proximity), while further into the casting the cells become larger and more spherical, indicating that they have grown relatively freely and unimpeded in the liquid regions. The transition from densely-packed to free growth (DFT) occurs some distance below the casting surface and is clearly distinguishable in the Na- and Sr-modified castings. The positions of the DFT are shown in Figures 1 and 2 as white broken lines.

The DFT for each sample (i.e. alloy type and cooling condition) was measured by the same technique as for CET, and the results are shown in Figure 5. Note that the DFT is unidentifiable in unmodified castings as the eutectic cell size is too small to clearly distinguish it. The transition from densely packed to unconstrained cells (DFT) varies somewhat between the three types of sands in the Na-modified alloys. It tends to be further from the casting surface in the zircon sand cast samples than in the silica and ilmenite cast samples, and further still in the presence of steel chills.

In the Sr-modified alloys the increase in cooling ability has less effect on the location of the CET and the DFT than in Na-modified alloys. However, it is clear that in Sr-modified alloys the DFT is closer to the surface of the casting than in Na-modified alloys, and that in the $12.5 \% \mathrm{Si}$ alloy cast in silica sand moulds the DFT does not exist because the shell of densely packed grains does not form at all.

\subsubsection{Cell Size and Shape}

Figure 6 shows a series of typical macrostructures of Na-modified Al-7\% and Al-12.5\% alloy castings made under different cooling conditions. They show that these alloys form a layer of fine eutectic cells close to the surface of the castings and that at some distance from the surface the cells become larger and appear to have grown largely unconstrained by other eutectic cells.

The eutectic cells near the surface of the castings exhibit a different shape as the cooling ability of the moulds increase. In the silica sand mould castings, the cells are quite large, in the order of 1 $\mathrm{mm}$, and almost spherical. As the cooling ability increases in ilmenite and zircon sand mould castings, the cells at the surface become more elongated. In the samples produced from the zircon moulds, the cells also become irregular in shape (in particular see Figure $6 \mathrm{c}$ and g). In the chill cast samples the rapid cooling leads to formation of fine spherical cells that are not discernible on the macro-images of Figure 6. Enlarged images of the near-surface microstructures of the Na-modified alloys are shown in Figure 7 to demonstrate more clearly the transition zones.

In the Sr-modified castings (Figure 8), the layer of densely packed cells is narrower and more difficult to resolve, particularly for the $7 \% \mathrm{Si}$ alloy. There is a thin layer of fine cells at the surface of the ilmenite and zircon sand castings, while in the silica sand castings this layer cannot be clearly 
distinguished. In some castings, a thin layer is found on one side of the sample but not on the other; this is most likely due to local variations in cooling.

As in the Na-modified castings the eutectic cells near the surface of the Sr-modified $12.5 \% \mathrm{Si}$ castings change from spherical to elongated as the mould material's cooling ability increases (Figure 8). In the chill cast samples the cells are too fine to be distinguished on the images. In the Sr-modified 7\% Si castings (Figure 8) increased cooling ability of the mould material has little effect on the shape and size of the eutectic cells; they remain spherical and relatively large, 1 to 3 $\mathrm{mm}$ in diameter.

An attempt was made to measure the diameter of the eutectic cells (or equivalent diameter for nonspherical cells) in different zones in the castings. However, it was impossible in some instances to clearly define the boundaries between cells and to acquire cell counts that would give statistically significant data for the eutectic cell size in all samples. Instead an attempt was made to estimate the cell size in the samples at 1 and $4 \mathrm{~mm}$ from the casting surface and in the centre of the castings. These data are presented in Table 3. The data show that in the unmodified castings the eutectic cell size is less than $0.1 \mathrm{~mm}$. In the Na-modified castings it is approximately larger by a factor of 10 . The cells in the Sr-modified castings are again twice the size of those in the Na-modified castings. It appears that in the Na-modified, near eutectic castings the cell size decreases in the centre of the castings indicating that as the fraction liquid decreases the cooling rate increases to a degree where more nuclei are activated such that the cell size is reduced.

\subsection{Interaction between Primary Grains and Eutectic Cells}

Primary Al grains are formed before the Al-Si eutectic during the solidification sequence. The Al-Si eutectic therefore forms and grows within free spaces that are governed by the primary phase morphology. However, the nature of eutectic growth within these spaces is dependent on other factors, i.e. composition and cooling.

On a macro level, it is the relative locations of the CET and the DFT in a casting that indicates the way the primary phase and the eutectic interact in particular regions. The CET and DFT positions for the different alloys and mould materials are shown in Figures 3 and 5. From these, it is possible to define the spatial distance between the CET and the DFT. These values, expressed as \% of half casting thickness, are shown in Figure 9. In the unmodified alloys the DFT cannot be found, therefore zone 2 is not shown in the graphs for those alloys in Figure 9.

\subsection{Location and Morphology of Pores}

The shape and distribution of porosity in the three zones for castings of each alloy/cooling condition is shown in Figure 10. It is shown, with one exception, that there are very few pores in zone 1. The exception is the unmodified, chill cast sample of the $7 \% \mathrm{Si}$ alloy and in this case a large agglomeration of pores are trapped on the boundary between zone 1 and zone 3 (zone 2 was not found in this alloy).

In zone 2 the largest area fraction and number density of pores are found in the Sr modified castings (Figure 10b and 10c, respectively). It is also clear that these pores exhibit the lowest roundness, see Figure 10a. Note that the relatively large variation in roundness (large confidence interval) stems from the fact that there are always some pores with roundness near 1.0 even though the majority of them have lower roundness. In the case of the Na-modified 7\% Si alloy sand cast sample there are very few pores in zone 2 , but these have a large scatter in roundness values and the confidence interval is very large. 
In the 7\% Si alloy the number of pores per unit area and the area \% porosity increases from unmodified to Na-modified to Sr-modified alloys with the chill cast samples having more pores than the sand cast samples.

Pores are found in all samples in zone 3. Figure $10 \mathrm{a}$ shows that they are rounder in the $12.5 \% \mathrm{Si}$ alloy that in the $7 \%$ alloy. It is clear from Figures $10 \mathrm{~b}$ and $10 \mathrm{c}$ that in the chill cast samples and in the Na-modified silica sand cast samples the pores are pushed into zone 3 from zones 1 and 2. Srmodified castings are the exception in this regard.

In general, pores are found trapped between, and are very much shaped by, the eutectic cells that surround them, i.e. they lie on cell boundaries. This is particularly clear in the modified castings (Figures 2,6-8) where cells are clearly delineated. The 7\% Si alloys contain a large fraction of aluminium dendrites, and as a result the pores are also shaped by the surrounding dendritic network, being more elongated and following the irregular contours of the dendrites. Since there are fewer dendrites (and usually of a more spindly shape) in the $12.5 \% \mathrm{Si}$ alloy the pores are not shaped to the same extent by the dendrites, but instead tend to be more rounded.

The interaction between dendritic grains and eutectic cells plays an important role in determining the location and shape of pores. Hence the absolute and relative positions of the DFT and CET become critical. Factors that increase the DFT (i.e. push it further from the surface) allow a surface layer to form that contains very little porosity. This is the case for unmodified and Na-modified alloys, and also for steel core chill castings.

Where the DFT is effectively zero (e.g. sand cast $\mathrm{Sr}$-modified $7 \%$ and $12.5 \% \mathrm{Si}$ alloys) cells are large even near the surface, and pores tend to form anywhere across the casting thickness irrespective of the local cooling conditions (Figure 7 and 10). Only in the chill cast $12.5 \%$ Si alloy is it possible to create a relatively porosity-free outer layer when Sr-modification is used.

It is noted that pores that form between the DFT and the CET tend to be irregular in shape and grow parallel to the heat flow, following the shape of the underlying directional columnar dendritic grains. Towards the centre of the castings (i.e. at distances greater than CET) where dendrites become equiaxed, the pores become more spherical, forming in the final liquid pools remaining between the equiaxed dendrites and eutectic cells.

\section{Discussion}

It is argued that the porosity distribution in a casting can be related to three specific zones that are defined by the positions of the DFT and the CET. Note, these proposed zones are not to be confused with the three classic zones (i.e. chill zone, columnar zone, equiaxed zone) commonly described in casting literature. The classic zones are defined only by primary $\alpha-A l$ dendrites growing under different thermal conditions. In the classic model, formation of eutectic cells is not considered.

In the present model, the first zone is the solid outer shell near the surface of the casting that lies outside both the CET and the DFT. In this region there is directional growth of the primary phase and planar growth of the eutectic. Porosity tends to be pushed towards the centre of the casting during solidification leading to a relatively porosity free layer as shown in Figures 6,8 and 10. The size of this layer for the different alloys and cooling conditions is given in Figure 5.

The second zone of the casting lies between the DFT and the CET. It is a transition layer where the primary phase growth is still columnar, but the eutectic growth is no longer planar. In this region feeding is less directional due to the interference of the primary phase and eutectic, more particularly, the breakdown of the eutectic growth front leading to isolated pockets of liquid towards the end of solidification, which lead to porosity formation. The morphology of the porosity 
tends to be irregular in shape as it is related to the growth morphologies of both the primary dendrites and the eutectic cells. Figure 9 shows the width of the three regions, relative to half the casting thickness, varies with modification and cooling ability of the moulds.

The third zone lies in the centre of the casting, inside both the CET and the DFT. Here the primary dendrites are equiaxed and the eutectic cell growth mode is free and cell size is strongly related to how the cells are modified. The porosity in this region tends to be relatively spherical; its size and position depending upon the growth morphology and size of the eutectic cells. Note; in thin walled castings, where columnar growth may extend to the centreline (i.e. no CET), this zone may not exist. The size of this zone is defined by the position of the CET with respect to the centreline location (see Figure 5).

What Figures 5 and 9 show is that the observed position of these zones, and indeed whether some of them exist at all, is highly dependent upon the modification state and the cooling ability of the mould. It should be remembered that the observed zones are the final product of two distinct solidification reactions that occur at different times and over different temperature ranges. The observation that the DFT occurs closer to the casting surface than the CET does, should not be taken to mean that it forms first. In fact, the deeper CET may be well established (formed at a higher critical thermal gradient) by the time the shallower DFT occurs (at an even lower thermal gradient).

Figure 11 is a schematic diagram showing the location of these regions with the arrows below indicating how melt treatment and process conditions interact to move the boundaries between the regions.

These three zones are now addressed in more detail.

\subsection{Zone 1 - The Outer Shell}

In this zone, columnar dendritic grains are largely unaffected by chemical modification. The SDAS for alloys of a given Si content cast in the same mould material is the same regardless of modification type. The effect of increased mould cooling ability is to slightly decrease the SDAS in zone 1, but the columnar growth mode remains because of a sufficiently high thermal gradient, even in sand moulds.

Between the primary dendrites that grow close to the casting surface, $\mathrm{Si}$ is rejected into the melt which eventually reaches the eutectic composition. Depending on the cooling ability of the mould material and the amount of primary dendrites formed the temperature gradient may be sufficient to allow the eutectic cells to nucleate at/near the surface and, at least for some time, form a coherent layer of directional eutectic cells between the established dendrites.

Zone 1 ends at the DFT where the local temperature gradient during eutectic solidification becomes so low (i.e. falls below a critical level, most likely alloy and cooling rate dependent) that the eutectic cells can nucleate ahead of the coherent layer but still within the network of columnar dendrites. The DFT position is closer to the surface in $7 \% \mathrm{Si}$ alloys than in $12.5 \% \mathrm{Si}$ alloys because there is a greater amount of latent heat released from primary solidification and therefore the temperature gradient is more quickly reduced.

In unmodified alloys eutectic cells nucleate easily and in presence of a temperature gradient a shell of fine cells forms that grows as an almost planar front dictated by the temperature field [10,21]. Horizontal arrows shown in Figure 11 indicate the relative effect of changing various process parameters. For example, the long arrow labelled "unmodified" at the interface between zones 1 and 
2 indicates that in unmodified alloys zone 1 is relatively wide compared to the same alloys when they are Na- or Sr-modified.

$\mathrm{Na}$ lowers the eutectic temperature (but with little recalescence), moves the eutectic point towards higher Si contents and reduces the number of active nuclei in the melt [22]. Therefore addition of $\mathrm{Na}$ has multiple effects on solidification: besides modifying the eutectic Si structure from acicular to fibrous, it increases the amount of primary dendrites formed [23] and increases eutectic cell size compared to the unmodified alloy. Altogether this means that the eutectic responds to local temperature gradients by forming a coherent shell of large eutectic cells near the surface of the castings. In Na-modified alloys, zone 1 is wider than in Sr-modified alloys but not as wide as in unmodified alloys.

$\mathrm{Sr}$ also reduces the number of active nucleation sites in the melt. However $\mathrm{Sr}$ has a much greater effect on nucleation than $\mathrm{Na}$. Undercooling prior to nucleation is larger in $\mathrm{Sr}$-modified alloys and the eutectic cell size is approximately 10 times greater than in unmodified alloys, see Table 3 and References [11,12]. Therefore Sr-modified alloys do not easily form a solid shell because eutectic nucleation is postponed until a large part of the casting is undercooled. Zone 1 is therefore relatively narrow or non-existent in these alloys.

The width of zone 1 depends strongly on cooling conditions, the greater the mould cooling ability the wider the zone. It is clear from Figures 2, 6 and 8 that in modified alloy castings (Sr-modified in particular) high cooling rates are necessary to make this region wider than a few millimetres.

Zone 1 is typically characterised by primary grains with small dendrite arm spacing and fine eutectic cells and is generally free from pores, facilitated by the "planar" eutectic growth front. Therefore the best mechanical properties are likely to be found in this region of the casting. The depth of zone 1 is important for many castings since subsequent machining operations may remove this sound layer and reveal sub-surface microporosity present in the less sound structure of zone 2 below. This type of porosity apart from being aesthetically unappealing can lead to problems with the quality of surface coatings applied.

\subsection{Zone 2 - The Transition Layer}

This zone lies between the DFT and CET for both types of modification and under all cooling conditions, as described in Figures 5 and 9, but there is no clear evidence that it is found in unmodified alloys. In this region, the thermal gradient conditions are still adequate for primary directional columnar dendrites to grow into the hotter liquid but conditions become insufficient for the eutectic to continue to grow in a planar manner. Within this region, the SDAS of the primary phase increases because the cooling rate decreases (Figure 4), but the growth mode remains columnar.

At the start of zone 2 (i.e. the DFT), the release of latent heat from the advancing columnar primary phase and planar eutectic changes the thermal conditions set up by the active cooling medium to below a critical level. At this point, nucleation and free growth of independent eutectic cells within the interdendritic spaces becomes possible (Figure 11).

Nucleation of the eutectic cells is a function of undercooling and the density of active nuclei [24]. The undercooling is determined by the balance between heat extraction through the solidified layer to the mould and latent heat released as the eutectic cells grow. It is well known that the growth velocity of the eutectic cells is also a function of the undercooling [2]. It is therefore most likely that the transition from dense to free growth is governed by a complex interaction between the spatial thermal gradient, cooling rate and nucleation kinetics. 
Zone 2 ends where the local thermal gradient falls to another critical level (also alloy and cooling rate dependent) that permits the CET to occur [6,25]. Increased cooling ability of the mould in general increases the depth at which the CET occurs, but because it also changes the depth of the DFT, the overall effect on the width of zone 2 is quite variable (Figure 9). The effect of increased cooling ability in widening zone 2 is significant in $7 \% \mathrm{Si}$ alloys but appears to be minimal in $12.5 \%$ $\mathrm{Si}$ alloys, regardless of modification type. Zone 2 is generally wide in the Sr-modified 7\% Si alloy but it is more dependent on cooling rate in the Na-modified alloy with the location moved deeper into the casting and its width increased with increased cooling rate. In the $12.5 \% \mathrm{Si}$ alloys the width of zone 2 is approximately constant for all cooling rates and melt treatments; however, it is pushed away from the surface, towards the centre of the casting with increased cooling rate. This effect is more pronounced in the Na-modified castings than in the Sr-modified alloy castings, particularly for steel chill and zircon sand conditions, see Figure 5.

At high cooling rates (particularly when steel chills are used, but also to some degree with zircon sand face cores) columnar dendritic grains grow further into the casting before the CET takes place. Nucleation of the eutectic is cooling rate dependent, increasing with increasing cooling rate, more so in the Sr-modified alloys than in the Na-modified alloys. This means that, in spite of the temperature gradient, the eutectic can nucleate anywhere in the zone 2 interdendritic liquid. As the cells form, recalescence causes local gradients to disappear. Therefore, in Sr-modified alloys zone 2 becomes wide and begins closer to the casting surface. In Na-modified castings the degree of recalescence is smaller and it takes a longer time for the temperature gradient to disappear and it is easier to maintain the gradient that leads to formation of a shell of eutectic cells. The result is that zone 2 begins further below the casting surface, and thus becomes narrower than in Sr-modified castings.

In general, pores that form in zone 2 between the DFT and CET are trapped between the dendritic grains and eutectic cells, see Figure 2. The dendritic network (growing perpendicular to the surface) in this zone tends to block centreline feeding in the plate casting and increases the tendency for porosity formation regardless of how good or bad the feeding conditions are, as shown in Figure 10. Resulting pores in this zone conform to the shape dictated by the directional dendrites and tend to become large, irregular and elongated in the growth direction of the dendrites. These types of pores are prevalent in all the 7\% Si alloys and near the surface of the silica sand core cast $12.5 \% \mathrm{Si}$ alloy when it is Sr-modified.

Large pores in zone 2 can be problematic for castings in highly stressed conditions, especially where they have been exposed on the surface after deep machining operations. The deeper that zone 2 starts, the less likely that these pores will be exposed. Large exposed pores can also be an aesthetic problem for many casting applications.

\subsection{Zone 3 - The Casting Centre}

This final region is determined by the location of the CET. Equiaxed dendrites form in this central zone where the thermal gradient is low and are accompanied by the free growth of spherical eutectic cells, see Figure 11. The macrographs in Figures 6 and 8 clearly show the equiaxed zone at the centre of the castings made with sand cores. Figure 4 shows that the SDAS changes little across the central region of the casting. Only in chill cast samples is it possible to maintain a thermal gradient towards the centre of the castings so that the SDAS gradually increases towards the centreline; however, even in these cases, equiaxed dendritic growth is usually found in a narrow zone at the centre. 
In the sand core cast samples zone 3 is typically wide, as shown in Figures 3, 6, and 8, accounting for up to one third of the total casting thickness. In these castings, large rounded pores are found homogeneously distributed within the zone, located between eutectic cells. Since the constricting primary grains are equiaxed rather than columnar in this zone, a rounded pore shape dominates over elongated forms more typically found in zone 2 (see Figure 10).

As described and sketched in Figure 11, increased cooling pushes the CET deeper into the casting. In the chill cast samples the pores are pushed by the advancing directional solidification front into the more slowly-cooled and increasingly narrow central zone. This tendency is also evident in the Na-modified alloys in the slower cooled conditions where the CET is moved deeper compared to corresponding Sr-modified and unmodified alloys.

Since the plates cast in this investigation are relatively thick walled $(15 \mathrm{~mm})$ compared to many aluminium castings produced commercially (e.g. $4-8 \mathrm{~mm}$ is common), it is quite likely that the CET (and hence zone 3) will not be found or will be very small in many of those castings. Additionally the use of grain refiners, as is common in industrial foundry practice [26], is likely to increase the size of zone 3 by moving the CET closer to the casting surface.

The unmodified and Na-modified alloys are able to form a solid shell while leaving the centreline of the castings open for feeding for a longer time; this has been discussed in more detail elsewhere [16]. Even though equiaxed eutectic cells form at the centre of the castings, it is still possible for the melt to move through the relatively open dendritic network. In the Sr-modified alloy, the earlier formation of free growth eutectic cells across the casting width means that the centreline feeding path is also blocked earlier; leading to increased porosity across the casting width [16].

Cooling conditions have great impact on the formation of porosity in this region. If a sufficient thermal gradient can be maintained towards the feeder it is possible to keep feeding paths open. This is easier in unmodified and Na-modified alloys and to some degree in the near eutectic alloy, particularly when it is Sr-modified. However, in these cases, it is possible that zone 3 may contain large amounts of concentrated porosity (see Figure 10). This type of porosity can become problematic in terms of mechanical performance if the effective defect sizes become very large.

\section{Conclusions}

The new model reasonably explains the wide range of microstructural features observed in the experimental hypoeutectic Al-7\% Si and near eutectic Al-12.5\% Si alloys in unmodified and modified $(\mathrm{Na}, \mathrm{Sr})$ forms cast as plates under various cooling conditions. It is proposed that there are two critical thermal gradients (both composition and cooling condition dependent) that govern the columnar to equiaxed transition (CET) of the primary $\alpha$-aluminium phase and the subsequent transition from densely packed to free growth (DFT) of the Al-Si eutectic. This delineates the casting into three zones: Zone 1 - an outer zone which tends to have little porosity, Zone 2 - a transition zone where porosity tends to be elongated and take the shape of the dendrites and eutectic cells and where feeding through the combined interdendritic and intercellular network is difficult, and Zone 3 - the central zone where porosity tends to be rounded and dispersed and feeding is possible if cooling conditions and casting geometry are optimised for the purpose. The type of modification and the cooling rate affects the relative sizes of each of these zones and consequently the final porosity distribution. This model provides a new way forward for the development of new generation numerical modelling that can predict porosity profiles within castings with much greater accuracy, be of greater value to the designer and assist in the selection of modification type to match casting conditions. 


\section{Acknowledgements}

CAST Cooperative Research Centre (CAST CRC) is established under and is funded in part by the Australian Federal Government's Cooperative Research Centres Scheme. Niels Tiedje gratefully acknowledges the support of CAST CRC during his period of research work at the University of Queensland.

The project was also partly funded by the Danish Foundry Organisation, Otto Mønsted's Foundation and Julie Damm's Foundation.

\section{References}

[1] Gao YX, Yi JZ, Lee PD, and Lindley TC. Acta Mater 2004;52:5435

[2] Fredriksson H and Åkerlind U. Materials Processing During Casting,Chichester: John Wiley; 2006.

[3] Porter DA and Easterling KE. Phase Transformations in Metals and Alloys, 2nd ed. Van Nostrand Reinhold (UK) Co. Ltd.; 1992.

[4] Pellini WS. American Foundryman 1953;24:62.

[5] Sigworth GK and Wang C. Metal Mater Trans B 1993;24:349.

[6] Gandin C. Acta Mater 2000;48:2483.

[7] Hunt JD. Mater Sci Eng 1984;65:75.

[8] Heiberg G, Nogita K, Dahle AK, and Arnberg L. Acta Mater 2002;50:2537.

[9] Felberbaum M and Rappaz M. Acta Mater 2011;59:6849.

[10] Flood SC and Hunt JD. Metal Science 1981;15:287.

[11] McDonald SD, Dahle AK, Taylor JA, and St.John DH. Metal Mater Trans A 2004;35A:1829.

[12] Dahle AK, Nogita K, McDonald SD, Dinnis C, and Lu L. Materials science \& engineering A, Structural materials: properties, microstructure and processing 2005;413-414:243.

[13] Nogita K, McDonald SD, Tsujimoto K, Yasuda K, and Dahle AK. J Electronmicroscop 2004;53:361.

[14] Otte MO. Porosity Formation in AlSi9Cu3 Alloy Castings. The Influence of Iron, Strontium, Sodium, Antimony and Bismuth. Dissertation. University of Queensland, Brisbane, Australia, Department of Mining, Minerals and Materials Engineering; 2000.

[15] Dinnis CM, Otte MO, Dahle AK, and Taylor JA. Metall Trans A 2004;35A:3531.

[16] Tiedje NS, Taylor JA, and Easton MA. Metal Mater Trans A 2012;43A:4846.

[17] Mathiesen RH, Arnberg L, Li Y, Meier V, Schaffer PL, Snigireva I, Snigirev A, and Dahle AK. Metal Mater Trans A 2011;42:170.

[18] Horai K and Simmons G. Earth Planet Sci Lett 1969;6:359.

[19] Moriya Y and Navrotsky A. J Chem Thermodyn 2006;38:211.

[20] Brinn MS, Friedman SJ, Gluckert FA, and Pickford RL. Industrial and Engineering Chemistry $1948 ; 1050$. 
[21] McDonald SD, Nogita K, and Dahle AK. Acta Mater 2004;52:4273.

[22] Hanna MD, Lu SZ, and Hellawell A. Metall Trans A 1984;15:459.

[23] Mannchen W and Tauscher L. Metall 1965;19:1052.

[24] Dahle AK, Nogita K, Zindel JW, McDonald SD, and Hogan LM. Metal Mater Trans A 2001;32A:949.

[25] Siqueira CA, Cheung N, and Garcia A. J Alloys Comp 2003;351:126.

[26] Spittle JA. Int J Cast Metals Res 2006;19:210.

\section{Tables}

Table 1: Thermal conductivity ( $k)$, density $(\rho)$, heat capacity $\left(c_{p}\right)$ and cooling ability $(\beta)$ for the various exchangeable core materials used. The "Index" value compares cooling ability relative to silica sand. Data is taken from several references. [18-20]

\begin{tabular}{l|ccccc} 
& $k$ & $\rho$ & $c_{p}$ & $\beta$ & Index \\
& $\mathrm{J} / \mathrm{m} \mathrm{K} \mathrm{s}$ & $\mathrm{kg} / \mathrm{m}^{3}$ & $\mathrm{~J} / \mathrm{K} \mathrm{kg}$ & $\begin{array}{c}\mathrm{J} / \mathrm{m} \mathrm{K} \\
\mathrm{s}^{1 / 2}\end{array}$ & - \\
\hline Silica & 0.60 & 1200 & 830 & 773 & 1.0 \\
Ilmenite & 0.84 & 1800 & 680 & 1016 & 1.3 \\
Zirconia & 1.60 & 2030 & 610 & 1408 & 1.8 \\
Steel & 43 & 7600 & 590 & 13886 & 18.0
\end{tabular}

Table 2: Composition (wt \%) of the nominal Al-7\% Si master alloy as given by the manufacturer.

$\mathrm{Al} \quad \mathrm{Fe} \quad \mathrm{Si} \quad$ Other elements

$\begin{array}{llll}92.77 & 0.11 & 7.08 & 0.04\end{array}$ 
Table 3: Approximate eutectic cell size in the various samples as function of distance from the casting surface for various alloy and cooling conditions. Note: the nomenclature designates the alloy Si content $(7,12.5)$, modification type (unmodified, UM; Na or Sr modification) and the mould face material (Silica sand or steel chill).

\begin{tabular}{|c|c|c|c|c|c|c|c|c|c|c|c|c|}
\hline \multirow{2}{*}{$\begin{array}{l}\text { Distance } \\
\text { from } \\
\text { surface } \\
(\mathrm{mm})\end{array}$} & \multicolumn{12}{|c|}{ Measured eutectic cell size $(\mathrm{mm})$} \\
\hline & $\begin{array}{l}7 \text { UM } \\
\text { Silica }\end{array}$ & $\begin{array}{l}7 \text { UM } \\
\text { Chill }\end{array}$ & $\begin{array}{l}7 \mathrm{Na} \\
\text { Silica }\end{array}$ & $\begin{array}{l}7 \mathrm{Na} \\
\text { Chill }\end{array}$ & $\begin{array}{l}7 \mathrm{Sr} \\
\text { Silica }\end{array}$ & $7 \mathrm{Sr}$ Chill & $\begin{array}{l}12.5 \mathrm{UM} \\
\text { Silica }\end{array}$ & $\begin{array}{c}12.5 \mathrm{UM} \\
\text { Chill }\end{array}$ & $\begin{array}{c}12.5 \mathrm{Na} \\
\text { Silica }\end{array}$ & $\begin{array}{c}12.5 \mathrm{Na} \\
\text { Chill }\end{array}$ & $\begin{array}{c}12.5 \mathrm{Sr} \\
\text { Silica }\end{array}$ & $\begin{array}{r}12.5 \mathrm{~S} \\
\text { Chill }\end{array}$ \\
\hline 1 & $<0.1$ & $<0.1$ & 0.6 & 0.2 & 1.7 & 0.2 & $<0.1$ & $<0.1$ & 1.7 & 0.2 & 3.2 & 0.1 \\
\hline 4 & $<0.1$ & $<0.1$ & 2 & 1.4 & 2.3 & 1.4 & $<0.1$ & $<0.1$ & 3.1 & 1.7 & 3.0 & 1.5 \\
\hline 7.5 & $<0.1$ & $<0.1$ & 2 & 1.4 & 2.2 & 1.4 & $<0.1$ & $<0.1$ & 1.8 & 0.8 & 3.7 & 2.1 \\
\hline
\end{tabular}




\section{Figures}

$7 \% \mathrm{Si}$, Na modified, sand cast

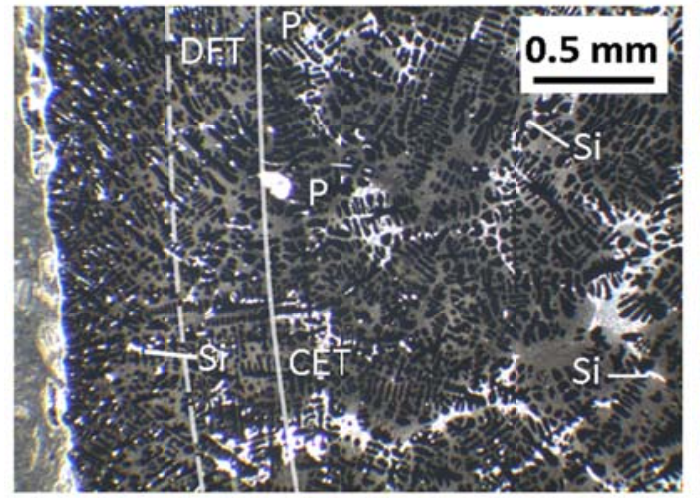

$12.5 \% \mathrm{Si}$, Sr modified, chill cast

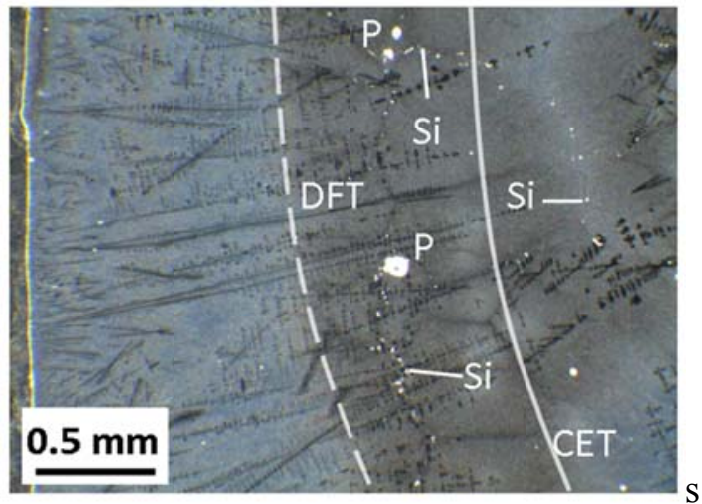

Figure 1: Typical macrostructures found in sand cast (left) and chill cast (right) alloys. Large Siparticles are marked "Si"; pores as " $\mathrm{P}$; the approximate location of the change in growth mode of eutectic cells is indicated as the broken white line "DFT"; and the change in growth mode of dendrites as the solid white line "CET". Note two different alloys are shown for comparison.
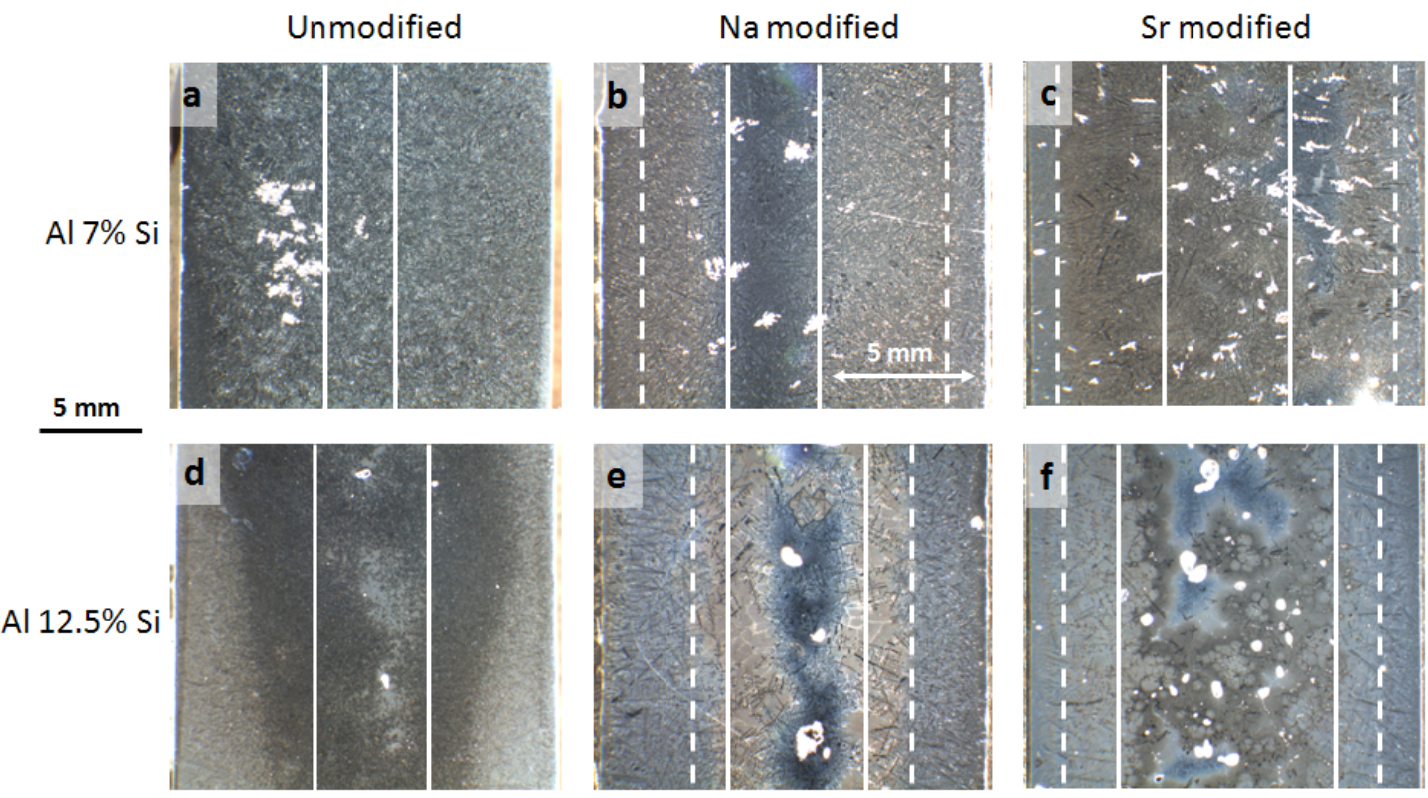

Figure 2: Typical macrostructures of samples taken from the chill cast plates for various alloy conditions. CET locations are indicated with continuous white lines and DFT locations are marked with broken white lines. There was no DFT observed for unmodified alloys. 


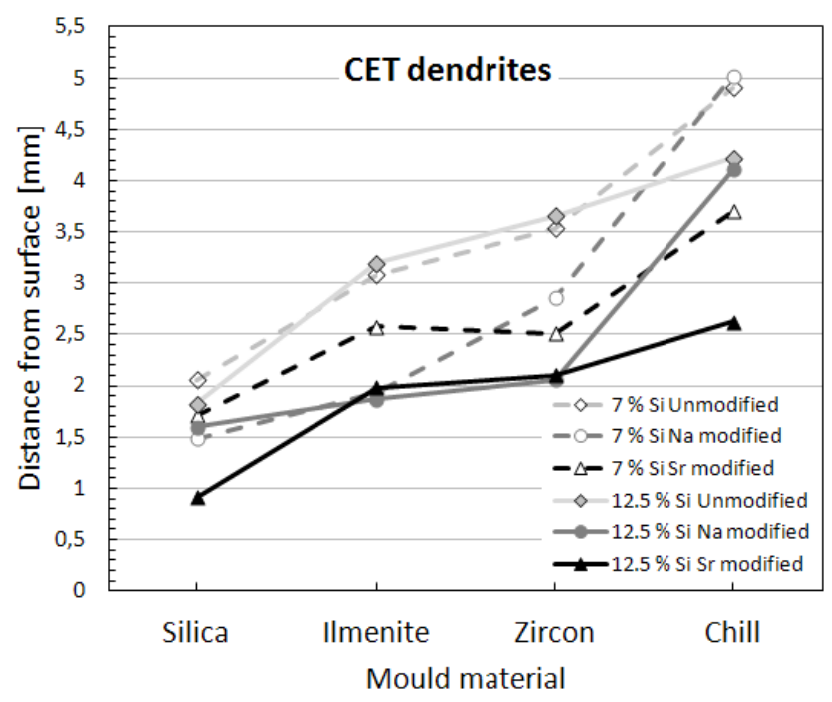

Figure 3: Plots showing the position where the transition from columnar to equiaxed dendritic grain growth (CET) takes place in castings for a range of alloys and cooling conditions. Although the $x$ axis is qualitative, it does represent in a semi-quantitative manner the increasing mould cooling ability, $\beta$.

a

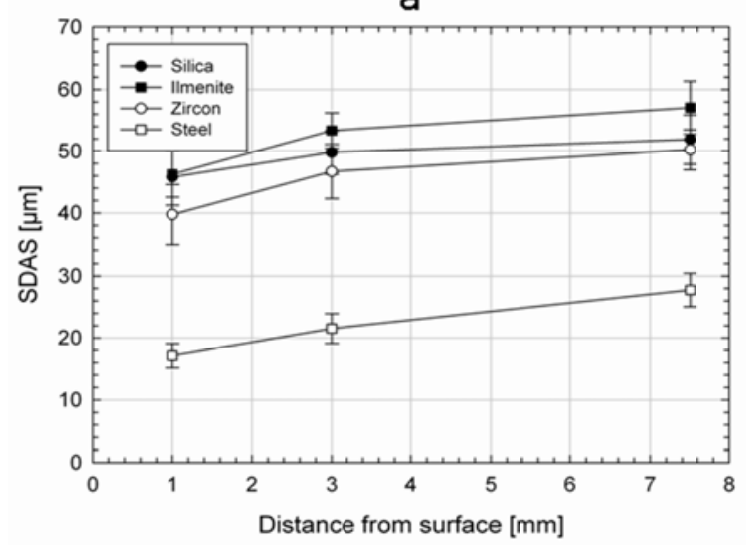

b

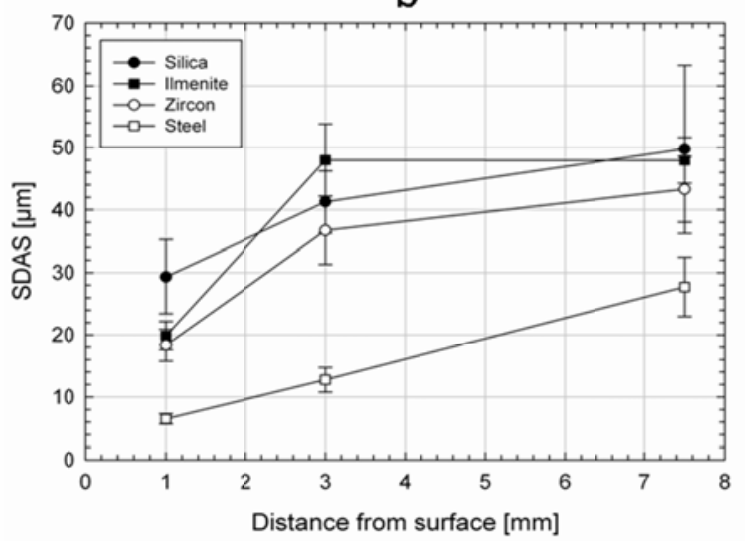

Figure 4: a) Secondary dendrite arm spacing (SDAS) as function of distance from the surface of the $7 \%$ Si alloy castings made using various core materials. b) Secondary dendrite arm spacing as function of distance from the surface of the $12.5 \%$ Si alloy castings made using various core materials. Note: unmodified, Na-modified and Sr-modified alloy variants of each set of conditions all showed the same SDAS. The bars indicate 95\% confidence levels. 


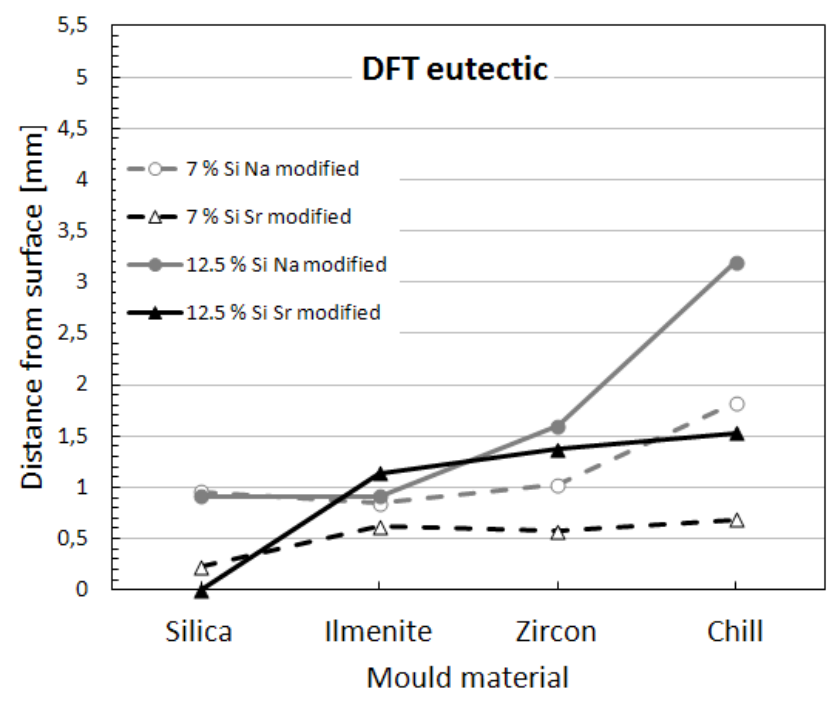

Figure 5: Plots showing the position where the eutectic growth transition from densely-packed to free growth (DFT) takes place in the castings for a range of alloys and cooling conditions. Note: the DFT could not be measured for the unmodified alloys. Although the $x$ axis is qualitative, it does represent in a semi-quantitative manner the increasing mould cooling ability, $\beta$. 

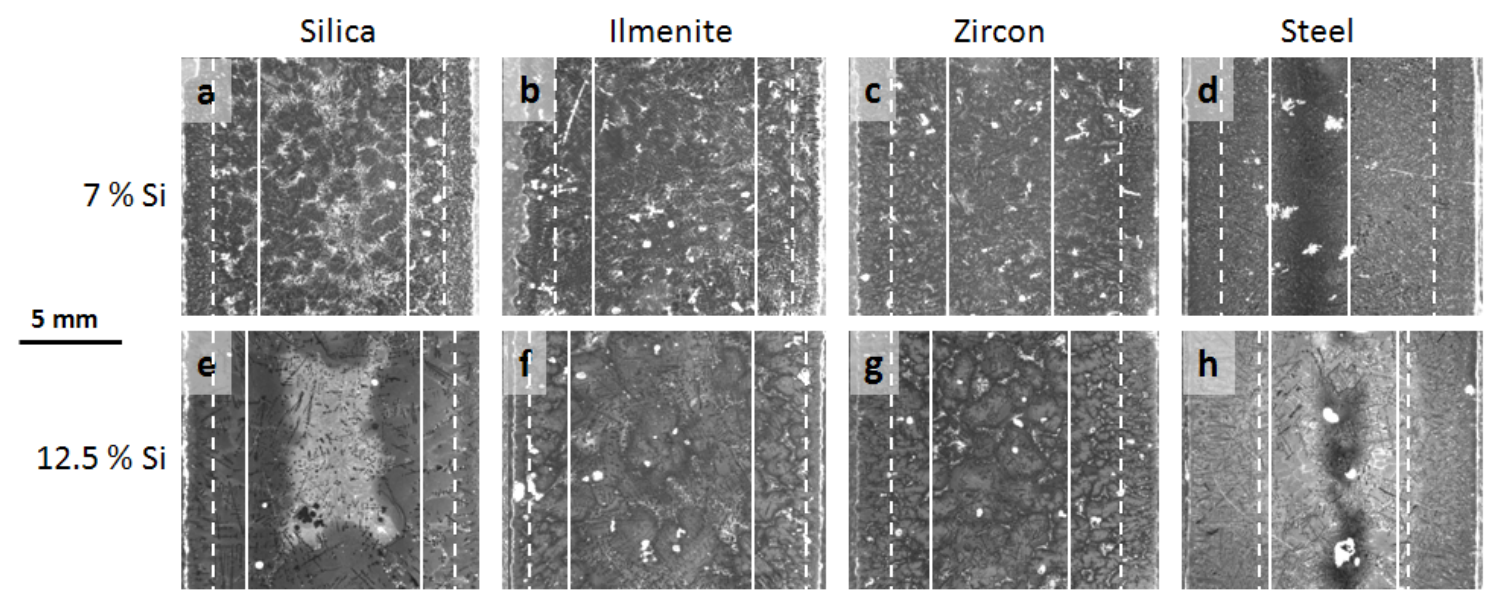

Figure 6: Typical macrostructures of Na-modified alloy samples taken from plates cast using different exchangeable core materials. The top row of images represents the 7\% Si alloy and the bottom row the $12.5 \%$ Si alloy. The scale bar shown is valid for all images.
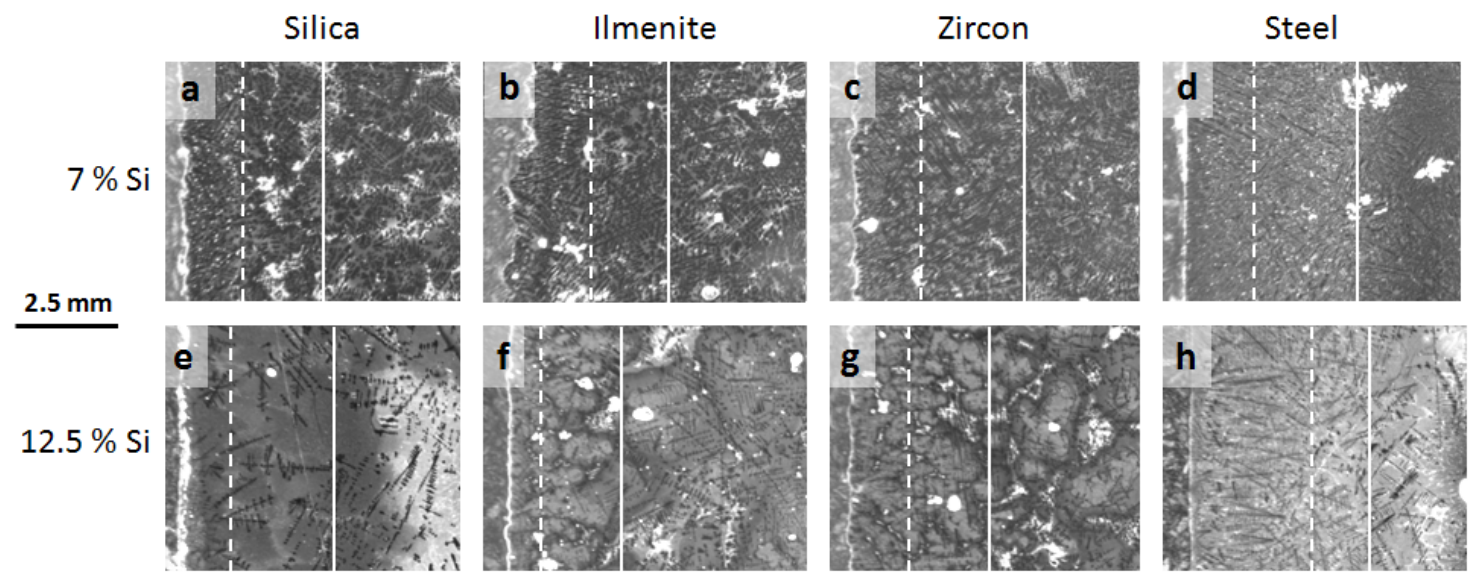

Figure 7: Enlarged sections of the Na-modified alloy samples shown in Figure 6. The images are taken near the surface of the castings, which is to the left in each picture. The scale bar shown is valid for all images. 

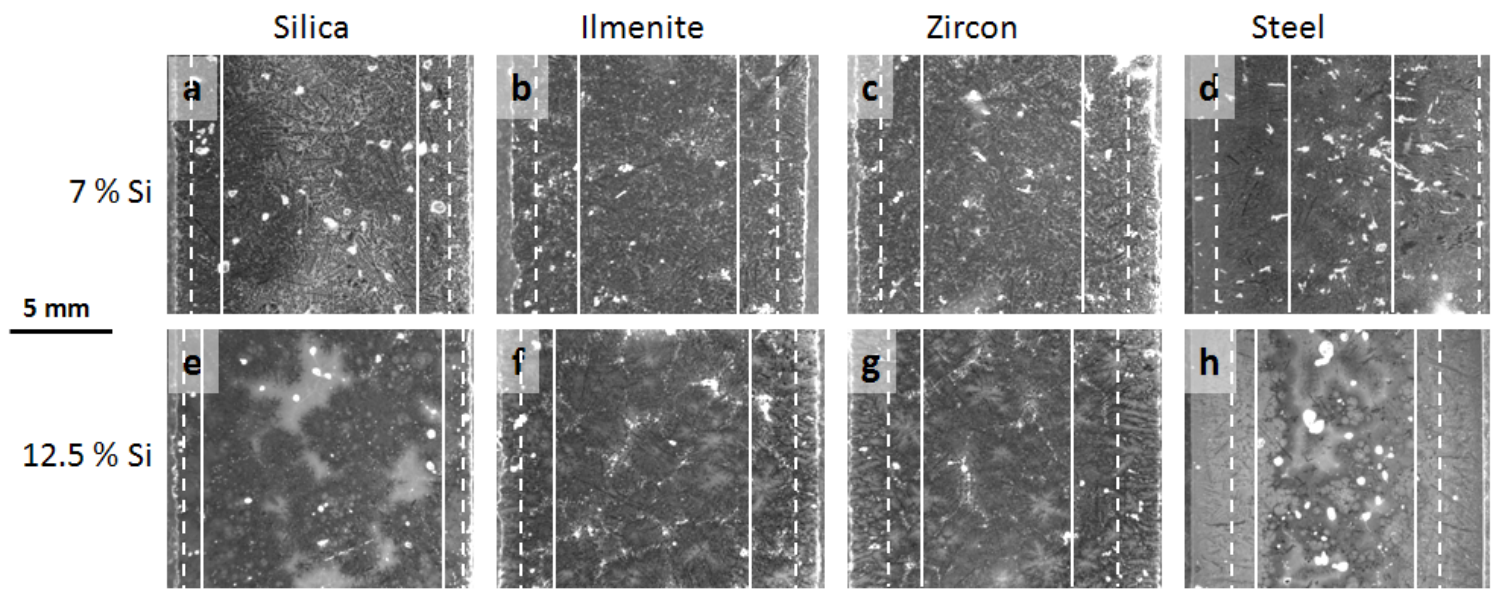

Figure 8: Typical macrostructures of Sr-modified alloy samples taken from plates cast using different exchangeable core materials. Other details as per Figure 6. 

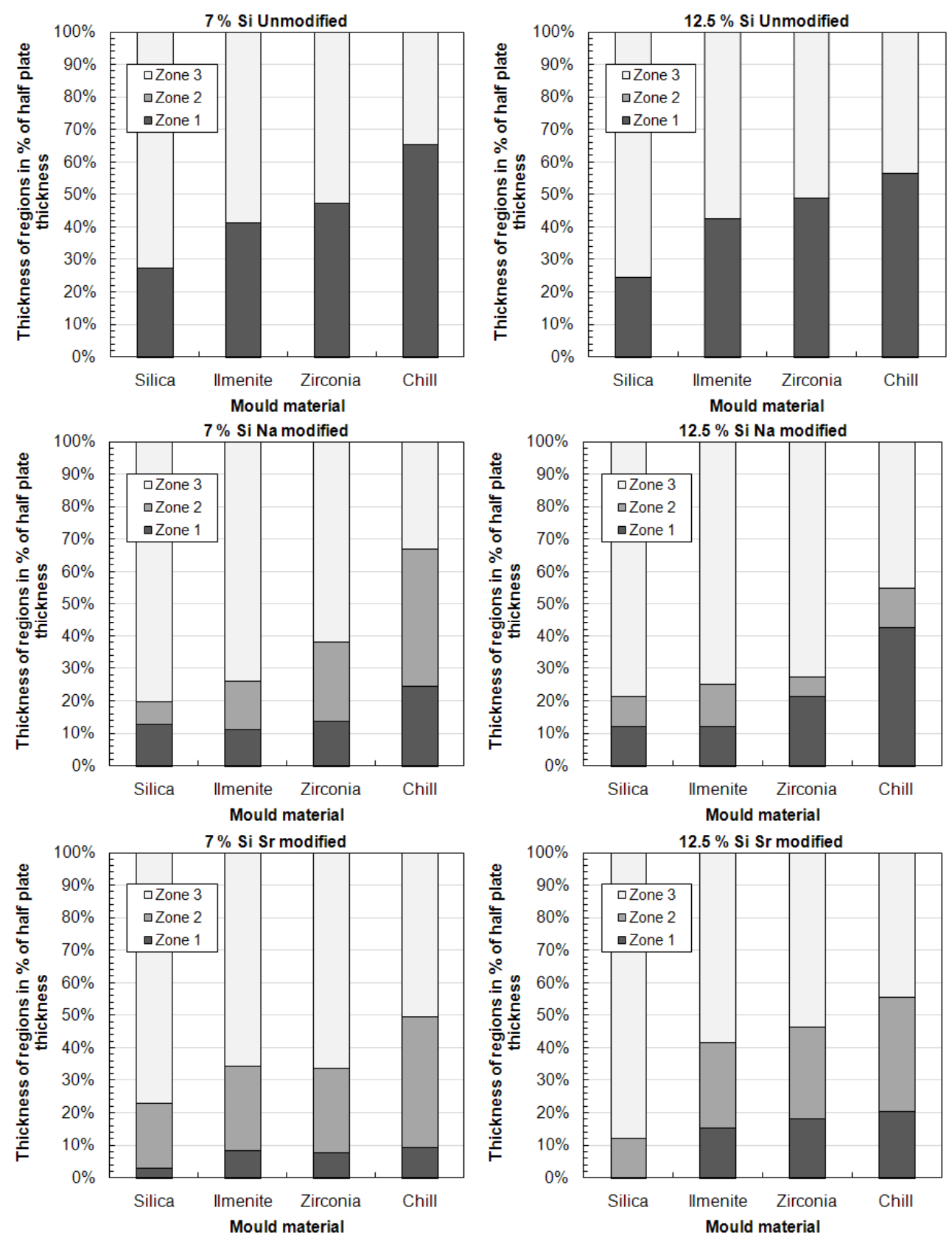

Figure 9: Width of the three regions relative to half the casting thickness for each combination of alloy, type of modification and cooling condition. Zone 1: The shell where eutectic cells grow close together between directional dendrites, i.e. outside the DFT. Zone 2: Between the DFT and CET where the eutectic cells are no longer densely packed but they still grow between the directional dendrites. This zone could not be found in the unmodified alloys. Zone 3: Inside the CET where large eutectic cells grow independently between equiaxed dendritic grains. The CET and DFT data are presented in Figures 3 and 5. 

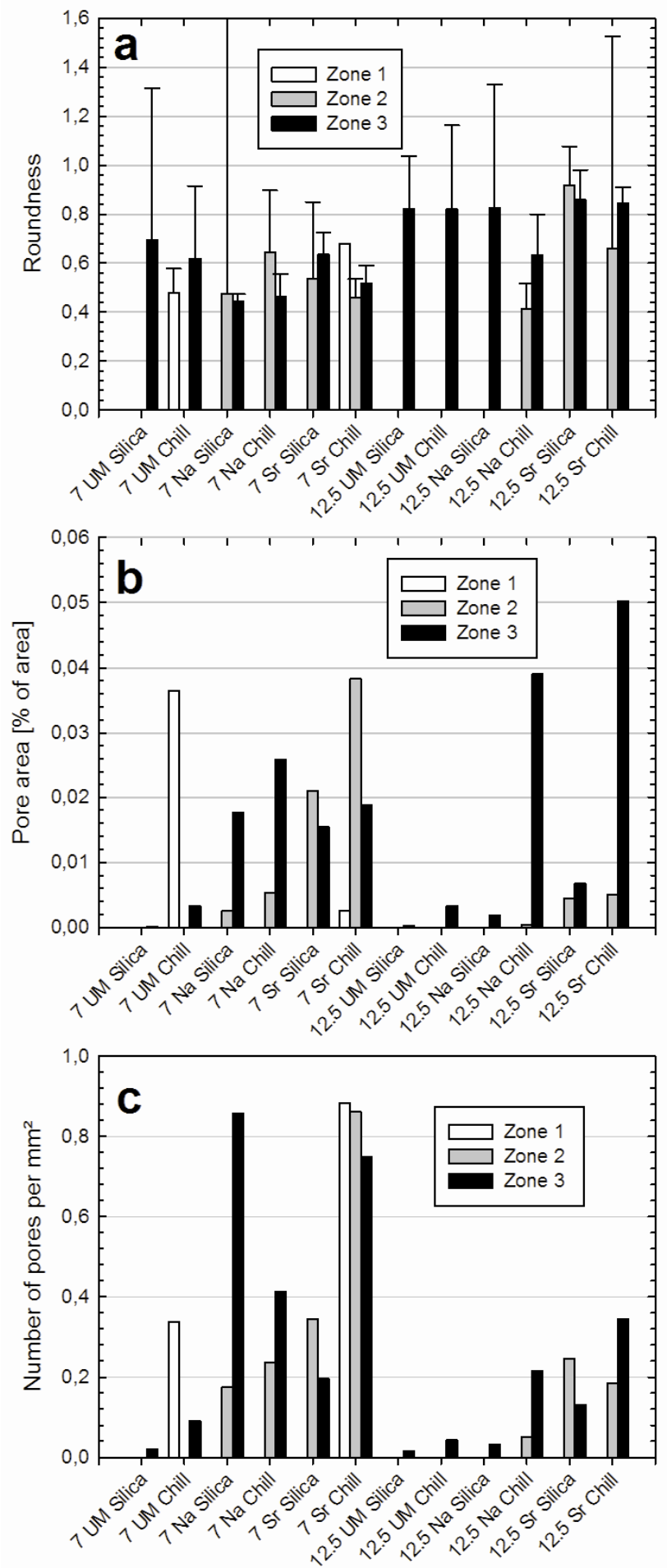

Figure 10: Graphs showing the shape and distribution of porosity in silica sand core and chill cast samples of the test alloys in the three zones: (a) The average roundness of pores with the 95\% confidence intervals also plotted; (b) Total pore area fraction in each zone expressed in \%; and (c) Number of pores per unit area. 


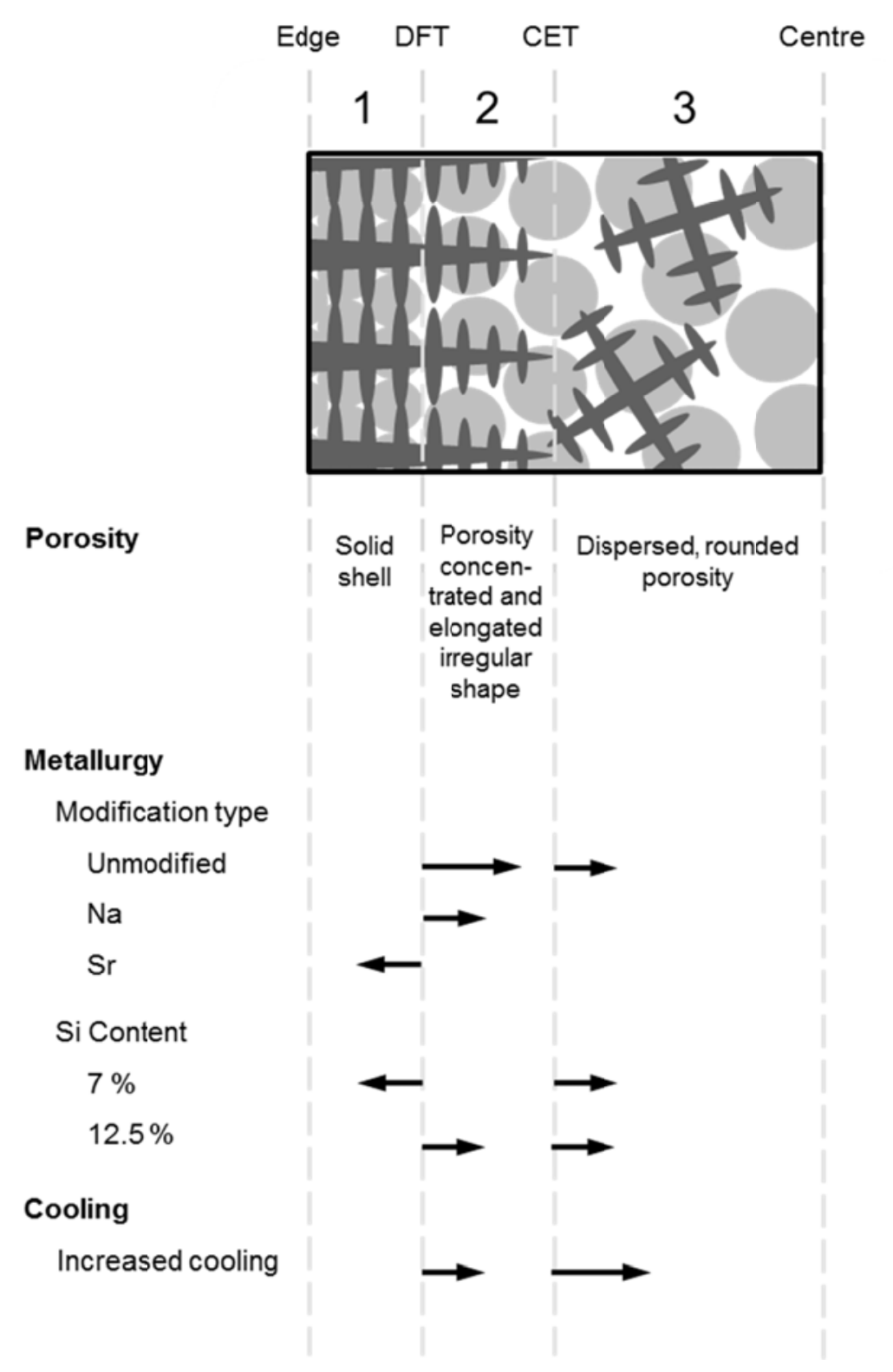

Figure 11: Schematic description of the formation of the three zones in the plate castings. The horizontal arrows below indicate how variations in cooling, modification and Si content influence the width of the regions. The length of the arrows indicates the relative power of changing the parameters. 